\title{
INFLUENCE OF FULVIC ACID PLUS SOME MICROELEMENTS AND MICROORGANISMS ON YIELD AND QUALITY CHARACTERISTICS OF SUPERIOR SEEDLESS GRAPEVINES EL-Boray, M.S. ${ }^{1}$; M.F. Mostafa ${ }^{1}$; A.D. Shaltout ${ }^{2}$ and K.H. Hassan ${ }^{3}$ \\ ${ }^{1}$ Pomology Dept., Fac. of Agric., Mansoura Univ. \\ ${ }^{2}$ Pomology Dept., Fac. of Agric., Ain Shams Univ. \\ ${ }^{3}$ Agric. Res. cent., Giza, Egypt.
}

\begin{abstract}
The present investigation was conducted during 2012, 2013 and 2014 seasons on 10-year-old Superior grapevines cultivar grown in a sandy soil, planted at $2 \mathrm{~m}$ within rows and $3 \mathrm{~m}$ between rows and irrigated using drip irrigation system at a private vineyard located at El-Khatatba, Menoufiya governorate, Egypt. The obtained data was discussed in details for the last 2 seasons only. The main objective of this investigation was to study the effect of fulvic acid foliar application $9 \mathrm{ml} /$ liter $/ \mathrm{vine}$, either alone or in combination with micro-elements $\left(\mathrm{Fe} \mathrm{SO}_{4} .7 \mathrm{H}_{2} \mathrm{O}\right.$ at $0.36 \mathrm{~g}+\mathrm{Zn}$ $\mathrm{SO}_{4} .7 \mathrm{H}_{2} \mathrm{O}$ at $0.18 \mathrm{~g}+\mathrm{MnSO}_{4} . \mathrm{H}_{2} \mathrm{O}$ at $0.18 \mathrm{~g}$ ) and bio-fertilizers (Trichoderma viride + Trichoderma harzianum + Serratia sp. + Pseudomonas fluorescens + Bacillus polymyxa) at $7.14 \mathrm{ml} /$ iter/vine $\left(10^{4} / \mathrm{ml}\right.$ per fungi and $10^{9} / \mathrm{ml}$ per bacteria viable cell) on vegetative growth, total chlorophyll content, yield, physical and chemical characteristics of cluster and quality of berries, total carbohydrates, total $\mathrm{N}$ and $\mathrm{C} / \mathrm{N}$ ratio in canes of Superior seedless grapevines. Results revealed that the combined treatment of fulvic acid, micro-elements plus bio-fertilizers induced indispensable positive effects for enhancing vegetative growth, total chlorophyll content, yield, physical and chemical characteristics of cluster and quality of berries, total carbohydrates, total $\mathrm{N}$ and $\mathrm{C} / \mathrm{N}$ ratio in canes of Superior grapevines. A stronger effect may probably support the hypothesis of that humic substances have different effects on plant adequately supplied with nutrients, in sustainable or organic viticulture for production of organic products, which can be a noteworthy alternative to synthesized chemicals fertilizers to produce a healthy product-free from their toxic residues and fit for export. Foliar spray applications of these products can have prospects for optimal economical use in terms minimizing the cost of production and in turn increased the income of vineyards.
\end{abstract}

Keywords: Fulvic acid; Microelements; Yield; Quality; Canes; Seedles.

\section{INTRODUCTION}

Grape (Vitis vinifera, L) is one of healthy and most important fruit crops. Its varieties have been adapted to different climates around the world, the area of grapevines cultivated exceeding 18.802 million feddan (OIV, 2006). Many cultivars have been developed for wine and table consumption as used in a wide variety of products; fresh fruit, preserves, juice, wine and raisins (Creasy and Creasy, 2009). In addition that, nutritional value of consuming fresh berries, which containing natural sugars, potassium and iron, which make the grape one of the very hygienic and popular fruits for many people all over the world.

In Egypt, Superior cultivar is an early-ripening cultivar, which ripens on the first to mid June. Some grape growers suffer greatly from the remarkable depression in the level of bud fertility, which is negatively reflected on the yield of 
this variety. $\mathrm{C} / \mathrm{N}$ ratio can directly helps to explain fruit bud formation (Winkler et al, 1965).

A great attention is focused on minimizing the intensive amounts of mineral nitrogen fertilization especially under sandy soils, which are naturally poor either in nutrient elements or organic matter through using supplementary organic $\mathrm{N}$ fertilizers as well as bio-fertilizers, which increased nutrient use efficiencies of crops in particular of fruit crops when such inoculants were added to either organic matter or soil (Sanga Khora and Weerakera, 1999).

In this respect, organic fertilization improves vegetative growth, nutritional status and reduces the residuals of nitrate and nitrite in grape berries and in turn using organic fertilizer will be promising in the long run for grapevines (Kassem and Marzouk, 2002 and Farag, 2006). Foliar fertilization can be absorbed from 8 to 20 times as efficient as ground application (Anonymous, 1985).

Fulvic acid is very active because of its low molecular weight, it has necessary and ability to readily bond minerals and elements into its molecular structure causing them dissolve and become mobilized fulvic complexes, Fulvic acid usually carries 70 or more mineral and trace elements as part of its molecular complexes, (Aiken et al., 1985). Fulvic acids are key ingredients of high quality foliar fertilizers. As they can help the penetration to the plant parts, stimulate the uptake of elements from plant surfaces into plant tissues. Once applied to leaves, fulvic acids transport trace minerals directly to metabolic sites within plant cells. Hence, foliar spray applications at specific plant growth stages, containing mineral chelated can be used as a primary technique for maximizing plants productive capacity (Chen et al., 2004).

Micro-elements are nutrient that applied in very low concentrations to the grapevine, but they play an essential role in vegetative and fruit development. These elements are more available at lower soil $\mathrm{pH}$, less available in leached sandy soils or are readily leached where the cation exchange capacity is low and the metal cations of zinc, manganese and iron are readily fixed by most soils. Therefore, soil application with synthetic chelated, which are usually quite effective can overcome these problems (Chen and Barak, 1982).

Biofertilizers are environment friendly, decreased agricultural costs with maximum output. These biofertilizers play an important role in enhancing crop productivity through nitrogen fixation, phosphate solubilization, plant hormone production, ammonia excretion and controlling various plant diseases. Biofertilizers enhance nutritional status of leaves could be related to the role of effective microorganisms in improving the availability of nutrients and to the modifications of root growth, morphology and physiology through hormonal exudates of biofertilizers bacteria and fungi resulting in more efficient absorption of available nutrients (EL-Gamal, 1996 and Eissa, 2003).

The present study was undertaken to investigate the effects of fulvic acid foliar application either alone or in combination with micro-elements ( $\mathrm{Fe}, \mathrm{Zn}$ and $\mathrm{Mn}$ ) and bio-fertilizers (Trichoderma viride + Trichoderma harzianum + Serratia $s p$. Pseudomonas fluorescens + Bacillus polymyxa) on vegetative growth, total chlorophyll content, yield, physical and chemical characteristics of cluster and quality of berries, total carbohydrates, total $\mathrm{N}$ and $\mathrm{C} / \mathrm{N}$ ratio in the canes of Superior seedless grapevines cultivar. 


\section{MATERIALS AND METHODS}

The present investigation was conducted during three successive seasons of 2012, 2013 and 2014. The work in the first year considered as a preliminary trial. The 10-year- old Superior grapevines were grown in a sandy soil, spaced at $2 \times 3$ meters apart ( $2 \mathrm{~m}$ within rows and $3 \mathrm{~m}$ between rows) and irrigated using drip irrigation system, in a private vineyard located at El-Khatatba, Menoufiya governorate, Egypt. Cane-pruned and trellised by using the Spanish baron supporting system. The vines were pruned on the first week of December in both seasons of study 96 eyes ( 8 canes x 12 buds/cane).

For this study, sixty three vines were chosen nearly uniform in vigor, all the chosen vines received the same cultural management that commonly performed in that district such as, fertilization, irrigation, diseases and pest control. The factorial experiment used was complete randomized block design.

Each three vines acted as a replicate and each three replicates were treated by one of the following treatments. Seven agricultural treatments were as follows:

$\mathrm{T}_{1}$ : Control (only water foliar spray).

$\mathrm{T}_{2}$ : Fulvic acid at $9 \mathrm{ml} /$ iter /vine.

$\mathrm{T}_{3}$ : Micro-elements $\left(\mathrm{FeSO}_{4} \cdot 7 \mathrm{H}_{2} \mathrm{O}\right.$ at $0.36 \mathrm{~g}+\mathrm{ZnSO}_{4} \cdot 7 \mathrm{H}_{2} \mathrm{O}$ at $0.18 \mathrm{~g}+$ $\mathrm{MnSO}_{4} \cdot \mathrm{H}_{2} \mathrm{O}$ at $\left.0.18 \mathrm{~g}\right) /$ liter /vine.

$\mathrm{T}_{4}$ : Bio-fertilizers (Trichoderma viride + Trichoderma harzianum + Serratia $s p$. + Pseudomonas Fluorescens+ Bacillus polymyxa) at $7.14 \mathrm{ml} / \mathrm{iter}$ /vine $\left(10^{4} / \mathrm{ml}\right.$ per fungi and $10^{9} / \mathrm{ml}$ per bacteria viable cell).

$T_{5}$ : Fulvic acid $\left(T_{2}\right)+$ Micro-elements $\left(T_{3}\right)$.

$T_{6}$ : Fulvic acid $\left(T_{2}\right)+$ Biofertilizers $\left(T_{4}\right)$.

$T_{7}$ : Fulvic acid $\left(T_{2}\right)+$ Micro-elements $\left(T_{3}\right)+$ Biofertilizers $\left(T_{4}\right)$.

All treatments were applied as foliar spray.

All previous treatments were sprayed at the following 4 stages:

1 - ${ }^{1}$ st stage was when new shoots reached about $15-20 \mathrm{~cm}$ length (first week of March)

2- ${ }^{2}$ nd stage was when clusters flower attained yellowish discoloration (one week before blooming).

3- ${ }^{3}$ rd stage was one week after fruit setting stage (second week of April).

4- ${ }^{4}$ th stage was when berries diameter reached 8-10 mm (first week of May).

Before commence of the experiment, soil samples were taken to determine mechanical and chemical properties of the experimental soil at three depths from surface, $(0-30,30-60$ and $60-90 \mathrm{~cm})$. Such samples in each category were completely mixed and subjected to mechanical and chemical analysis to measure certain properties of soil as included in Table1. 
Table 1. Mechanical and chemical properties of the experimental vineyard soil.

\begin{tabular}{|c|c|c|c|c|}
\hline \multicolumn{2}{|l|}{ Soil characters } & $0-30 \mathrm{~cm}$ & $30-60 \mathrm{~cm}$ & $60-90 \mathrm{~cm}$ \\
\hline \multirow{5}{*}{$\begin{array}{l}\text { Mechanical analysis } \\
(\%)\end{array}$} & Coarse sand & 8.72 & 4.13 & 3.94 \\
\hline & Fine sand & 69.63 & 70.91 & 71.20 \\
\hline & Silt & 12.48 & 13.84 & 14.49 \\
\hline & Clay & 9.17 & 11.12 & 11.57 \\
\hline & Texture class & Sandy & Sandy & Sandy \\
\hline \multirow{5}{*}{$\begin{array}{l}\text { Chemical analysis } \\
(\%)\end{array}$} & EC $(1: 5) d S . m^{-1}$ & 1.19 & 1.31 & 1.25 \\
\hline & $\mathrm{pH}(1: 2.5)$ & 8.16 & 8.05 & 8.09 \\
\hline & SP (\%) & 32 & 34 & 39 \\
\hline & $\mathrm{OM}(\%)$ & 0.59 & 0.46 & 0.29 \\
\hline & Total $\mathrm{CaCO}_{3}(\%)$ & 6.73 & 4.18 & 3.77 \\
\hline \multirow{6}{*}{ Available (mg/kg) } & $\mathrm{N}$ & 21.5 & 18.6 & 14.3 \\
\hline & $P$ & 2.92 & 3.05 & 2.75 \\
\hline & $\mathrm{K}$ & 183 & 171 & 167 \\
\hline & $\mathrm{Zn}$ & 1.03 & 0.84 & 0.67 \\
\hline & $\mathrm{Fe}$ & 2.17 & 1.79 & 1.54 \\
\hline & $\mathrm{Mn}$ & 1.61 & 1.12 & 1.05 \\
\hline
\end{tabular}

EC = Electrical conductivity of soil saturation extract.

$\mathrm{Sp}=$ Saturation percent.

$\mathrm{OM}=$ Organic matter.

Preparation of fulvic acid:

Compost (prepared from rice straw, farmyard manure, rock phosphate, bentonite and urea) was digested with $0.5 \mathrm{~N} \mathrm{KOH}$ for $48 \mathrm{~h}$ at room temperature in the ratio of $1 / 10(\mathrm{~W} \backslash \mathrm{V})$. Separation of the solute form the undigested residues were then carried out by filtration by 100 mesh screen. The supernatant was acidified at $\mathrm{pH} 2$ with concentrated $\mathrm{H}_{2} \mathrm{SO}_{4}$ and left for $24 \mathrm{~h}$ in the dark in order to allow humic acid flocculation. Fulvic acid collected by filtration. (Vallini et al. 1990). Fulvic acid data analyses were recorded in Table 2.

Table 2. Chemical analysis of fulvic acid.

\begin{tabular}{|l|c|}
\hline Trait & Value \\
\hline $\mathrm{pH}$ & 2.8 \\
\hline $\mathrm{EC}(\mathrm{dS} / \mathrm{m})$ & 8.68 \\
\hline Organic-C $(\%)$ & 2.81 \\
\hline Available $-\mathrm{N}(\mathrm{ppm})$ & 210 \\
\hline Available -P (ppm) & 7.4 \\
\hline Total $-\mathrm{K}(\%)$ & 2.26 \\
\hline
\end{tabular}

\section{Preparation of microorganisms:}

Serratia $s p$, are grown on peptone-glycerol media (Grimont and Grimont,1984), Pseudomonas fluorescens grown on king's media and Bacillus polymyxa grown on nutrient broth media (Alef, 1995) and Trichoderma species grown on Potato dextrose media (ATTC, 1992) were incubated for 2-3 days at 28 OC to maintain populations of $3 \times 108$ colony forming unit $\mathrm{ml}^{-1}$ (CFUIml). All microbial strains were kindly provided from Dept. of Microbiology, Soils, Water and Environment Research Institute (SWERI), Agriculture Research Center (ARC) Giza, Egypt 


\section{1- Measurements during vegetative growth stage:}

Growth vigor of vine was estimated by the measurement of certain growth indices carried out on each of the tested vines during the two experimental seasons after two weeks from the last addition in the two seasons of study (last week of May) such indices included:

1- Average shoot length $(\mathrm{cm})$ :

Shoot length was calculated by measuring the average length of 4 shoots / vine (shoot from each side)

2- Average shoot diameter (cm):

The same previous shoots were used to determine average diameter of the middle of the second basal internode by using veriner caliper.

3- Average leaf surface area ( $\mathrm{cm}^{2} /$ leaf):

Representative sample of four mature leaves per each treated vine (6th or 7th leaf from the top of the same previous shoots) that were taken from the different vine sides and used for leaf surface area measurements according to the following equation (Montero et al. 2000):

$$
\text { Leaf surface area }\left(\mathrm{cm}^{2} / \text { leaf }\right)=0.587(\mathrm{~L} \times \mathrm{W})
$$

Where, $L=$ Length of leaf blade, $\quad W=$ Width of leaf blade.

4- Leaf chlorophyll pigments ( $\mathrm{mg} / \mathrm{g}$ fresh weight):

Total chlorophylls content were determined in the previous leaves used for leaf surface area determination, it was estimated by taken 4 mature leaves from each side vine, as a representative sample at the 6th or 7 th leaf from the shoot tip. Fresh leaf sample of $0.05 \mathrm{~g}$ was used, soaked in $10 \mathrm{ml}$ methanol for 24 hours in cool chamber after adding a trace from sodium carbonate (Robinson and Britz, 2000), then leaf chlorophyll pigments were determined spectrophotometrically. The amount of chlorophyll present in the extract was calculated using the following equations introduced by (Arnon, 1949).

$$
\begin{gathered}
\text { Ch.A }=16.5 O D_{665}-8.3 O D_{650} \\
\text { Ch.B }=33.8 O_{650}-12.5 O D_{665} \\
\text { Total chlorophyll }=25.5 O D_{650}+4.0 O_{665}
\end{gathered}
$$

Where, $\mathrm{OD}=$ Optical density at wave length of 650 and $665 \mathrm{~nm}$

$$
\text { Total chlorophyll }(\mathrm{mg} / \mathrm{g} \text { fresh weight })=\frac{\text { Total chl. } \times \text { Volume of solution }}{- \text { Weight of sample } \times 1000}
$$

II- Measurements at harvest time:

1- Yield (kg/vine):

At harvest time, when the soluble solids content percentage in berry juice reached to $16 \%$, (10 and 7 June in 2013 and 2014, respectively) the yield expressed in weight $(\mathrm{kg})$ was estimated by multiplying number of clusters per vine by the average weight of cluster.

2- Cluster characteristics:

Number of clusters was recorded. A sample of 12 clusters/treatment, 4 clusters from each replicate were harvested and transported to the laboratory of 
Pomology Dept., Mansoura University to determine physical and chemical properties of clusters and berries.

\section{1- Average cluster weight (g):}

This was estimated in grams by using an electrical sensitive balance.

3- Berry chemical characteristics:

3.1- Soluble solids content percentage (SSC \%):

This was measured by using a carlzeiss according to (Chen and Mellenthim, 1981).

\section{2- Titratable acidity (\%)}

It was determined by titrating $5 \mathrm{ml}$ of clear juice against $\mathrm{NaOH}(0.1 \mathrm{~N})$ after the addition of a few drops of phenolphthalein (ph.th) as an indicator. The total titratable acid was expressed as $\mathrm{mg}$ of tartaric acid in $100 \mathrm{ml}$ juice. The formula used in this respect was from AOAC (1984).

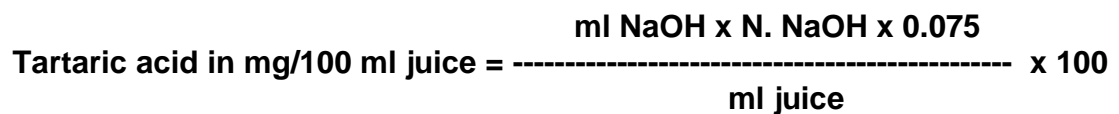

Where:

0.075 = Milliequivalent weight of tartaric acid

$\mathrm{N}=$ Normality of $\mathrm{NaOH}(0.1 \mathrm{~N})$

\section{3- Soluble solids content / acid ratio}

This ratio was calculated by dividing the percentage of SSC on total titratable acidity.

\section{4- Nitrate and nitrite content in berries (ppm)}

\section{Measurements after harvest:}

It was determined according to the method described by Singh (1988).

\section{1- Total carbohydrates in canes (\%):}

For determination of total carbohydrates in canes, , the canes per each replicate were cut, oven dried at $70{ }^{\circ} \mathrm{C}$ till a constant weight and finely grinded, then, $0.1 \mathrm{~g}$ of samples was submerged over night in $10 \mathrm{ml}$ of $80 \%(\mathrm{v} / \mathrm{v})$ ethanol at $25{ }^{\circ} \mathrm{C}$ with periodic shaking. The ethanolic mixture was filtered and the ethanolic filtrate was made up to known volume. Carbohydrates first hydrolyzed into simple sugars using dilute hydrochloric acid. In hot acidic medium glucose is dehydrated to hydroxymethyl furfural. This compound forms with anthrone a green colored product with an absorption maximum at $620 \mathrm{~nm}$, standard curve was prepared by taking $0,0.2,0.4,0.6,0.8$ and $1 \mathrm{ml}$ of glucose. Amount of carbohydrates present in $100 \mathrm{~g}$ of the sample $=\mathrm{mg}$ of glucose/volume of test sample x 100 (Hedge and Hofreiter, 1962).

\section{2- Total nitrogen in canes (\%):}

For determination of total nitrogen in canes, the canes per each replicate were cut, oven dried at $70{ }^{\circ} \mathrm{C}$ till a constant weight and finely grinded. Then, $0.2 \mathrm{~g}$ crude dried powder from each sample was wet digested with a mixture of concentrated sulphuric acid and perchloric acid, then heated until become clear solutions (Peterburgski, 1968). After digestion, the clear solution was quantitatively transferred into $50 \mathrm{ml}$ measuring flask with distilled water and kept for determinations. The modified micro-kjeldahl apparatus of Parnars and Wagner as described by Jones et al. (1991) was used for total nitrogen determination according to the method of AOAC (1984). 


\section{3- $\mathrm{C} / \mathrm{N}$ ratio in canes:}

The obtained ratio was calculated by dividing the percentage of total carbohydrates on total nitrogen.

\section{Statistical analysis:}

The obtained data of this study were statistically analyzed according to the technique of analysis of variance (ANOVA) for the complete randomized blocks design according to the method described by Gomez and Gomez (1984). The treatment means were compared using the New Least Significant Differences (New LSD) according to the producers outlined by Waller and Duncan (1969). A significance level of $5 \%$ was used for all statistical analysis.

\section{RESULTS AND DISCUSSION}

Shoot length (cm):

As shown in Table 4 all tested treatments significantly increased average shoot length in both seasons of the study as compared to that of control treatment $\left(T_{1}\right)$. The combined application (Fulvic acid + Microelements + Biofertilizers) recorded a significant increase of average shoot length $(193.00 \&$ $213.90 \mathrm{~cm}$ ) comparing to other treatments under the study in the two seasons, respectively. The other tested treatments recorded intermediate values in both seasons. The lowest values of shoot length were observed at the control treatment $(129.00$ and $138.80 \mathrm{~cm})$.

These results agreed with the findings of Ferrara et al., (2007), Abd ElWahab, (2011), Shaheen et al., (2012) and Ahmed et al., (2011), who stated that using the suitable N via 60 to $80 \%$ inorganic form plus 5 to $10 \mathrm{~cm}^{3} /$ vine/ season Fulvic acid and Spirulina platensis algae significantly stimulated main shoot length compared with using $\mathrm{N}$ completely via inorganic form or with using inorganic $\mathrm{N}$ at percentage lower than $60 \%$. Reducing percentage of inorganic $\mathrm{N}$ from 100 to $60 \%$ and at the same time increasing percentages of organic and bio-fertilizers from 0.0 to $10 \mathrm{~cm}^{3} /$ vine/ season were accompanied by a gradual stimulation on such growth character. Abd El-Hameed et al., (2014) using the suitable $\mathrm{N}$ in form of inorganic $\mathrm{N} 30$ to $75 \%$ besides organic and biofertilization with Fulvic acid and (EM) each at 10 to $20 \mathrm{ml} / \mathrm{vine} / \mathrm{year}$ significantly stimulated shoots length rather than using $\mathrm{N}$ as inorganic $\mathrm{N}$ at $3075 \%$ alone.

This positive effect of combination can be attributed to the nutrient contents in their extracts with special emphasis to biological function of nitrogen in plant life. It is being a part of proteins, enzymes, amino acids, polypeptides and many other biochemical compounds in plant system. Therefore, it is required for survival of each plant cell (Mengel and Kirkby, 1987). Moreover, applied compost tea to the plant foliage, provides beneficial micro-organisms and nutrients to the surface of the plant as well as assists the plant to suppress certain diseases and increases nutrients availability (Biocycle, 2004). 
Table 3. Effect of organic, microelements and bio-fertilizers on the vegetative growth of Superior seedless grapevines during 2013 \& 2014 seasons.

\begin{tabular}{|l|c|c|c|c|c|c|}
\hline \multirow{2}{*}{ Treatment } & \multicolumn{2}{|c|}{$\begin{array}{c}\text { Shoot length } \\
\text { (cm) }\end{array}$} & \multicolumn{2}{c|}{$\begin{array}{c}\text { Shoot diameter } \\
\text { (cm) }\end{array}$} & $\begin{array}{c}\text { Leaf surface area } \\
\text { (cm }\end{array}$ \\
\cline { 2 - 7 } & $\mathbf{2 0 1 3}$ & $\mathbf{2 0 1 4}$ & $\mathbf{2 0 1 3}$ & $\mathbf{2 0 1 4}$ & $\mathbf{2 0 1 3}$ & $\mathbf{2 0 1 4}$ \\
\hline Control & 129.00 & 138.80 & 1.10 & 0.95 & 119.10 & 122.40 \\
\hline Fulvic acid & 175.00 & 188.70 & 1.40 & 1.53 & 127.00 & 128.60 \\
\hline Microelements & 150.00 & 166.60 & 1.27 & 1.40 & 134.50 & 135.00 \\
\hline Bio-fertilizers & 170.00 & 183.10 & 1.53 & 1.60 & 141.80 & 143.30 \\
\hline Fulvic acid + Microelements & 181.70 & 196.50 & 1.60 & 1.73 & 153.70 & 158.00 \\
\hline Fulvic acid + Bio-fertilizers & 183.00 & 203.60 & 1.67 & 1.87 & 146.10 & 147.10 \\
\hline Fulvic acid + Microelements + \\
Bio-fertilizers & 193.00 & 213.90 & 1.80 & 2.23 & 160.00 & 162.40 \\
\hline New LSD at 5\% & 5.50 & 5.90 & 0.17 & 0.19 & 4.30 & 3.90 \\
\hline
\end{tabular}

Bio-fertilizers = (Trichoderma viride + Trichoderma harzianum + Serratia sp. + Pseudomonas fluorescens + Bacillus polymyxa) at $7.14 \mathrm{ml} /$ liter /vine.

Micro-elements $=\left(\mathrm{FeSO}_{4} .7 \mathrm{H}_{2} \mathrm{O}\right.$ at $0.36 \mathrm{~g}+\mathrm{ZnSO}_{4} .7 \mathrm{H}_{2} \mathrm{O}$ at $0.18 \mathrm{~g}+\mathrm{MnSO}_{4} . \mathrm{H}_{2} \mathrm{O}$ at $\left.0.18 \mathrm{~g}\right) / \mathrm{liter}$ /vine.

\section{Shoot diameter $(\mathrm{cm})$ :}

It is obvious from data in Table 4 that there were significant differences between all treatments rather than control treatment concerning average shoot diameter, sole and combined applications greatly increased average shoot diameter, (Fulvic acid + Microelements + bio-fertilizers) and (Fulvic acid + biofertilizers) treatments significantly increased average shoot diameter (1.80 and $2.23 \mathrm{~cm})$ and $(1.67 \& 1.87 \mathrm{~cm})$ in both seasons, respectively. The sole treatments had in between values. Control vines had lowest values of average shoot diameter $(1.10 \& 0.95 \mathrm{~cm})$ during the two seasons of study, respectively.

These results are in accordance with those obtained by Ferrara et al. (2007), Abd El-Wahab, (2011) and El-Sabagh et al., (2011) on Thompson seedless grapevines, they studied the possibility of reducing the amount of mineral fertilizers by using different sources of bio- fertilizers and they found that the highest values of canes diameter was that of vines received mineral nitrogen fertilization combined with bio fertilizers. Likewise, Ahmed et al., (2011) revealed that the applications of both humic acid (HAs) generally increased shoot diameter. Shaheen et al., (2012) reported that vines received compost in presence of bio-fertilizers and humic acid significantly increased canes diameter of Crimson seedless grapevines.

The positive effect may be due to the great availability of nutrients and hence stimulating cell division and cell enlargement as well as presence of natural hormones associated with biofertilizers application (Nijjar, 1985).

Leaf surface area $\left(\mathrm{cm}^{2}\right)$ :

It is clear from Table 4 that all tested treatments significantly increased average leaf surface area compared to the control treatment. So, treating vines with treatment $T_{7}$ (Fulvic acid + Microelements + Bio- fertilizers) gave the highest significant values of average leaf surface area $\left(160.00 \& 162.40 \mathrm{~cm}^{2}\right)$ comparing to other treatments during both seasons of the study respectively, followed by $T_{5}$ (Fulvic acid + Microelements treatment). However, the untreated vines had the 
lowest values of leaf surface area $\left(119.10 \& 122.40 \mathrm{~cm}^{2}\right)$, during the two seasons of study, respectively.

Our data go in line with those reported by El-Sabagh et al., (2011) who illustrated that adding bio-fertilizers caused an increment in leaf area of Thompson seedless grapevines. In the same line, Khalil, (2012) on Flame seedless grapevines found that highest leaf area was obtained with vines fertilized with $100 \%$ of the recommended mineral fertilization plus bio-fertilizers. In addition, Megawer, (2009) working on Superior grapes, Shaheen et al. (2012) on Crimson seedless grapes and Ali et al., (2013) on Thompson seedless grapevines, stated that adding humic acid with bio-fertilizers effectively maximized leaf surface area. Abd El-Hameed et al., (2014) stated that using the suitable $\mathrm{N}$ in form inorganic $\mathrm{N} 30$ to $75 \%$ besides organic and biofertilization with Fulvic acid and (EM) each at 10 to $20 \mathrm{ml} /$ vine/year significantly stimulated leaf area rather than using $\mathrm{N}$ as inorganic $\mathrm{N}$ at $3075 \%$ alone.

The beneficial effect of organic fertilizers on leaf surface area of plants could be related to providing energy from micro-organisms activity, increasing nutrient supply and improving the efficiency of macro- elements as well as its ability to meet some micro-nutrients requirements (El-Nagar, 1996).

The positive merits of using of fulvic acid and biofertilizers on vegetative growth might be attribute to the following reasons they effectively enhanced availability of nutrients, antioxidants, natural hormones such as IAA, GA3 and cytokines, vitamin B, and enzymes such as nitrogenase (Abd El- Hameed et al. 2014)

\section{Leaf chlorophyll pigments:}

Data concerning leaf chlorophyll pigments (mg/g FW) are presented in Table 5 it could be concluded that single and combined applications significantly increased chlorophyll A, chlorophyll B and total leaf chlorophyll pigments content comparing with control treatment, vines foliar spraying with the combined of (Fulvic acid + Microelements + bio-fertilizers) was significantly increased to the total leaf chlorophyll pigments content (chlorophyll $A$, chlorophyll $B$ and total chlorophyll $(A+B)(0.397 \& 0.412,0.216 \& 0.236$ and $0.612 \& 0.652 \mathrm{mg} / \mathrm{g} \mathrm{FW})$ in both seasons of this study, respectively. Otherwise, the control treatment had insignificant values.

These results are in agreement with those obtained with Ferrara et al., (2007) and Ferrara and Brunetti (2010), who illustrated that application of humic acid was able to increase chlorophyll contents values in Italia grapevines leaves. In addition, Ali et al., (2013) found that humic acids with bio-fertilizers had significant effective role in increasing total leaf chlorophyll content in Thompson seedless grapevines leaves. Abd El- Hameed et al., (2014) using the suitable N in form inorganic N 30 to $75 \%$ besides organic and biofertilization with Fulvic acid and (EM) each at 10 to $20 \mathrm{ml} / \mathrm{vine} / \mathrm{year}$ significantly stimulated chlorophyll a \& chlorophyll $\mathrm{b}$ and total chlorophyll $(\mathrm{a}+\mathrm{b})$ rather than using $\mathrm{N}$ as inorganic $\mathrm{N}$ at 30 to $75 \%$ alone. 
Table 4. Effect of organic, microelements and bio-fertilizers on chlorophyll A, $B$ and total chlorophyll in leaves of Superior seedless grapevines during 2013 \& 2014 seasons.

\begin{tabular}{|l|c|c|c|c|c|c|}
\hline \multirow{2}{*}{ Treatment } & \multicolumn{2}{|c|}{$\begin{array}{c}\text { Chlorophyll A } \\
\text { (mg/g FW) }\end{array}$} & \multicolumn{2}{c|}{$\begin{array}{c}\text { Chlorophyll B } \\
\text { (mg/g FW) }\end{array}$} & $\begin{array}{c}\text { Total chlorophyll } \\
\text { (mg/g FW) }\end{array}$ \\
\cline { 2 - 7 } & $\mathbf{2 0 1 3}$ & $\mathbf{2 0 1 4}$ & $\mathbf{2 0 1 3}$ & $\mathbf{2 0 1 4}$ & $\mathbf{2 0 1 3}$ & $\mathbf{2 0 1 4}$ \\
\hline Control & 0.351 & 0.367 & 0.185 & 0.197 & 0.536 & 0.565 \\
\hline Fulvic acid & 0.354 & 0.373 & 0.189 & 0.202 & 0.543 & 0.575 \\
\hline Microelements & 0.365 & 0.384 & 0.192 & 0.205 & 0.557 & 0.589 \\
\hline Bio-fertilizers & 0.373 & 0.390 & 0.199 & 0.210 & 0.573 & 0.599 \\
\hline Fulvic acid + Microelements & 0.388 & 0.404 & 0.210 & 0.224 & 0.597 & 0.628 \\
\hline Fulvic acid + Bio-fertilizers & 0.377 & 0.401 & 0.205 & 0.221 & 0.582 & 0.621 \\
\hline $\begin{array}{l}\text { Fulvic acid + Microelements + } \\
\text { Bio-fertilizers }\end{array}$ & 0.397 & 0.416 & 0.216 & 0.236 & 0.612 & 0.652 \\
\hline New LSD at 5\% & 0.007 & 0.007 & 0.006 & 0.005 & 0.006 & 0.010 \\
\hline
\end{tabular}

Bio-fertilizers = (Trichoderma viride + Trichoderma harzianum + Serratia sp. + Pseudomonas fluorescens + Bacillus polymyxa) at $7.14 \mathrm{ml} /$ liter /vine.

Micro-elements $=\left(\mathrm{FeSO}_{4} \cdot 7 \mathrm{H}_{2} \mathrm{O}\right.$ at $0.36 \mathrm{~g}+\mathrm{ZnSO}_{4} .7 \mathrm{H}_{2} \mathrm{O}$ at $0.18 \mathrm{~g}+\mathrm{MnSO}_{4} \cdot \mathrm{H}_{2} \mathrm{O}$ at $\left.0.18 \mathrm{~g}\right) / \mathrm{liter}$ /vine.

Measurements after harvest:

Yield/vine (kg):

Data presented in Table 5 showed that treating vines with (Fulvic acid + Bio-fertilizers) alone or combined with Micro-elements significantly increased yield per vine in the two seasons as compared with other treatments or the control. In both seasons, it can be noticed, that yield per vine (11.64 \&12.88 $\mathrm{kg} / \mathrm{vine}$ ) and (12.33 \& $13.45 \mathrm{~kg} / \mathrm{vine})$ respectively, were recorded when vines treated with (Fulvic acid + Bio-fertilizers) and (Fulvic acid + Micro-elements + Biofertilizers), compared to untreated vines which gained $(8.04 \& 8.16 \mathrm{~kg} / \mathrm{vine})$.

Table 5. Effect of organic, microelements and bio-fertilizers on yield per vine and cluster weight of Superior seedless grapevines during 2013 \& 2014 seasons.

\begin{tabular}{|l|c|c|c|c|}
\hline \multirow{2}{*}{ Treatment } & \multicolumn{2}{|c|}{$\begin{array}{c}\text { Yield/vine } \\
\text { (kg) }\end{array}$} & \multicolumn{2}{c|}{$\begin{array}{c}\text { Cluster weight } \\
\text { (g) }\end{array}$} \\
\cline { 2 - 5 } & $\mathbf{2 0 1 3}$ & $\mathbf{2 0 1 4}$ & $\mathbf{2 0 1 3}$ & $\mathbf{2 0 1 4}$ \\
\hline Control & 8.04 & 8.16 & 524.10 & 508.60 \\
\hline Fulvic acid & 11.47 & 11.95 & 593.80 & 581.90 \\
\hline Microelements & 9.19 & 9.79 & 551.80 & 600.00 \\
\hline Bio-fertilizers & 11.30 & 11.81 & 607.00 & 568.80 \\
\hline Fulvic acid + Microelements & 10.89 & 11.18 & 616.30 & 578.50 \\
\hline Fulvic acid + Bio-fertilizers & 11.64 & 12.88 & 592.10 & 560.00 \\
\hline Fulvic acid + Microelements + Bio- \\
fertilizers & 12.33 & 13.45 & 649.97 & 605.00 \\
\hline New LSD at 5 \% & 0.47 & 0.38 & 32.84 & 21.59 \\
\hline
\end{tabular}

Bio-fertilizers = (Trichoderma viride + Trichoderma harzianum + Serratia sp. + Pseudomonas fluorescens + Bacillus polymyxa) at $7.14 \mathrm{ml} / \mathrm{liter} / \mathrm{vine}$.

Micro-elements $=\left(\mathrm{FeSO}_{4} .7 \mathrm{H}_{2} \mathrm{O}\right.$ at $0.36 \mathrm{~g}+\mathrm{ZnSO}_{4} .7 \mathrm{H}_{2} \mathrm{O}$ at $0.18 \mathrm{~g}+\mathrm{MnSO}_{4} \cdot \mathrm{H}_{2} \mathrm{O}$ at $\left.0.18 \mathrm{~g}\right) / \mathrm{liter}$ /vine.

Similar results were reported by Akgül et al., (2007) reported that, in Sultani Çekirdeksiz grape cultivar, zinc fertilizer in the form of $\mathrm{ZnSO}_{4} .7 \mathrm{H}_{2} \mathrm{O}$ at 0.50 and $0.25 \%$ dose levels increased grape yield and improved quality 
characteristics of berries. Megawer, (2009) on Superior seedless grapevines and Shaheen et al., (2012) on Crimson seedless grapevines mentioned that yield of tested grapevines increased by using humic acid and bio- fertilizers. Abd ElHameed et al., (2014) using the suitable $\mathrm{N}$ via mineral $\mathrm{N}$ at 60 to $75 \%$ of the suitable $\mathrm{N}$ with Fulvic acid and (EM) each at $15 \mathrm{ml}$ was very effective in improving the yield comparing with using $\mathrm{N}$ completely via mineral $\mathrm{N}$ or when mineral $\mathrm{N}$ was applied at percentage lower $60 \%$.

Humic substances have different effects on plants showed evidence of stimulation on plant growth by humic substances and consequently increased yield by acting on mechanisms involved in: cell respiration, photosynthesis, protein synthesis, water, and nutrient uptake, enzyme activities. (Chen et al. 2004).

Physical and chemical characteristics of clusters and berries.

Cluster weight (g):

Data in Table 5 clearly showed differences in cluster weight as affected by all treatments during the two seasons of study, in this point view, treating vines with (Fulvic acid + Microelements + Bio-fertilizers) produced the highest increase of clusters weight $649.97 \mathrm{~g}$ in the ${ }^{1}$ st season and $605.00 \mathrm{~g}$ in the ${ }^{2}$ nd season, followed by (Fulvic acid + Microelements) $616.30 \& 578.50 .0 \mathrm{~g}$ in the ${ }^{1} \mathrm{st}$ and ${ }^{2}$ nd seasons, respectively.

These results are in harmony with those reported by Megawer, (2009) on Superior seedless grapevines and Shaheen et al., (2012) on Crimson seedless grapevines, they all mentioned that cluster weight of tested grapevines increased by using humic acid and biofertilizers. Moreover, El-Sabagh et al., (2011) and Khalil, Hoda (2012) studied the effect of replacing the excessive application of mineral fertilizers partially with bio-fertilizers, they found that the highest values of cluster weight were recorded by vines treated with biofertilizers. Shamseldin et al., (2010) found that bio-fertilizer inoculation with strain of Pseudomonas fluorescens on Washington navel orange trees had increased fruit weight by a rate of $(33.25 \%$ and $31.6 \%)$ in the first and second seasons.

As for the effect of organic and bio-fertilizers on improving both physical and chemical properties of the grapes, the beneficial effect of organic and biofertilizers on fruit quality could attributed to the effect of nutrient content of the vines, which accelerated the formation of carbohydrates (Ezz, 1999). The great availability of nutrients is stimulating cell division and cell enlargement as well as natural hormones in producing larger fruits (Nijjar, 1985).

Soluble solids content (\%), Titratable acidity (\%) and SSC/acid ratio:

Soluble solid content in Table 6 generally revealed significant increase at the tested treatments in comparison to control treatment. (Fulvic acid + Biofertilizers) and (Fulvic acid + Microelements+ Bio-fertilizers) combined treatments recorded the highest significantly increased of SSC\%, where recorded (17.10 and $17.50 \%)$ and $(17.50$ and $17.20 \%)$ for the two seasons of study, respectively.

Likewise, similar effects were recorded concerning SSC/ acid ratio measurements. On the other hand, as for total titratable acidity, the same treatments showed the lowest values as compared to other treatments $(0.63$ and $0.59 \%)$ and $(0.61$ and $0.60 \%)$ in the two seasons of study, respectively. The combined foliar application of these materials improved the chemical quality of berries in terms of increasing total soluble solids content (\%), total soluble solids/ 
acid ratio and reducing the total titratable acidity of berries juice than the single application of these materials and control treatment in the two seasons of the study.

The previous results are in line with those reported by El-Shenawy \& Fayed (2005) and Rizk-Alla, (2006), they worked on different grape cultivars and concluded that application of bio- fertilizers may be affect berry maturity through increasing exchangeable $\mathrm{K}, \mathrm{Ca}$ and $\mathrm{Mg}$, which decreasing acidity by the formation of potassium tartrate salts, which are relatively insoluble. Moreover, Stino et al., (2009) reported that the increase in leaf content of nitrogen leads to increase photosynthesis and thereby increase the proportion of carbohydrates in the leaves. Megawer, (2009) on different grapevines cultivars, they all reported that fertilizing vines with inorganic and organic fertilizers with or without biofertilizers improved quality of the berries in terms of increasing SSC\%, SSC/acid ratio and decreasing acidity in berry juice. Shaheen et al., (2012), they assured that all berry chemical characteristics i.e. total soluble solids, total acidity contents significantly increased by successive application of sources and rates of compost, bio fertilizers, humic acid and natural rocks treatments for the two seasons compared to control. Abd El- Hameed et al.,(2014) using the suitable $\mathrm{N}$ via mineral $\mathrm{N}$ at $30 \%$ of the suitable $\mathrm{N}$ with Fulvic acid and (EM) each at $25 \mathrm{ml}$ was more effective in improving the solid soluble content \& acidity and total sugar comparing with using $\mathrm{N}$ completely via mineral $\mathrm{N}$ or when mineral $\mathrm{N}$ was applied at percentage lower than $60 \%$.

Table 6. Effect of organic, microelements and bio-fertilizers on SSC \%, titratable acidity \% and SSC/acid ratio of Superior seedless grapevines during $2013 \& 2014$ seasons.

\begin{tabular}{|l|c|c|c|c|c|c|}
\hline \multirow{2}{*}{ Treatment } & \multicolumn{2}{|c|}{ SSC (\%) } & \multicolumn{2}{c|}{$\begin{array}{c}\text { Titratable } \\
\text { Acidity (\%) }\end{array}$} & \multicolumn{2}{c|}{ SSC/acid ratio } \\
\cline { 2 - 7 } & $\mathbf{2 0 1 3}$ & $\mathbf{2 0 1 4}$ & $\mathbf{2 0 1 3}$ & $\mathbf{2 0 1 4}$ & $\mathbf{2 0 1 3}$ & $\mathbf{2 0 1 4}$ \\
\hline Control & 14.70 & 15.00 & 0.86 & 0.84 & 17.00 & 17.80 \\
\hline Fulvic acid & 16.50 & 16.70 & 0.67 & 0.64 & 24.60 & 26.10 \\
\hline Microelements & 15.70 & 16.30 & 0.73 & 0.69 & 21.60 & 23.60 \\
\hline Bio-fertilizers & 16.00 & 16.60 & 0.70 & 0.67 & 22.40 & 24.80 \\
\hline Fulvic acid + Microelements & 16.40 & 16.80 & 0.68 & 0.64 & 23.90 & 26.40 \\
\hline Fulvic acid + Bio-fertilizers & 17.10 & 17.50 & 0.63 & 0.59 & 27.00 & 29.80 \\
\hline $\begin{array}{l}\text { Fulvic acid + Microelements + Bio- } \\
\text { fertilizers }\end{array}$ & 17.50 & 17.20 & 0.61 & 0.60 & 28.60 & 28.70 \\
\hline New LSD at 5\% & 0.94 & 0.51 & 0.023 & 0.022 & 1.44 & 1.17 \\
\hline
\end{tabular}

Bio-fertilizers = (Trichoderma viride + Trichoderma harzianum + Serratia sp. + Pseudomonas fluorescens + Bacillus polymyxa) at $7.14 \mathrm{ml} /$ liter $/$ vine.

Micro-elements $=\left(\mathrm{FeSO}_{4} .7 \mathrm{H}_{2} \mathrm{O}\right.$ at $0.36 \mathrm{~g}+\mathrm{ZnSO}_{4} .7 \mathrm{H}_{2} \mathrm{O}$ at $0.18 \mathrm{~g}+\mathrm{MnSO}_{4} \cdot \mathrm{H}_{2} \mathrm{O}$ at $\left.0.18 \mathrm{~g}\right) /$ liter /vine.

The combined foliar application of Fulvic acid, Microelements plus Biofertilizers improved the chemical quality of berries in terms of increasing the total soluble solids, total soluble solids/ acid ratio and reducing the total acidity than the sole foliar application of these materials ,the enhancing of Fulvic acid, Microelements and Bio-fertilizers on chemical properties of the berries may be interpreted to its role in achieving a good balance between vegetative growth and fruiting through nutrients availability which is reflected its turn on increasing the 
accumulation of total carbohydrate and resulting the stimulation of ripening. (Li et al., 1999).

\section{Nitrate and nitrite in berries (ppm):}

The results in Table 7 showed that nitrate and nitrite content in berries of grapevines under the tested treatments were statistically differed compared with the control treatment in both years study. Nitrate and nitrite significantly increased resulted in berries of the control treatment; they were $7.19 \& 6.76 \mathrm{ppm}$ and 1.28 \& 1.31ppm during the two seasons respectively, followed by fulvic acid treatment. Moreover, the addition of (Fulvic acid + Microelements + Bio- fertilizers) led to a significant reduce of nitrate and nitrite content in berries of grapevines when compared with the control treatment especially in the second season, which recorded $6.86 \& 4.70 \mathrm{ppm}$ for $\mathrm{NO}_{3}$ and $1.16 \& 0.92 \mathrm{ppm}$ for $\mathrm{NO}_{2}$.

These results are in agreement with those reported by Farag, (2006) emphasized that high content of nitrate and nitrite was found in $100 \%$ mineral fertilization, while organic fertilization caused a sharp reduction of nitrate and nitrite of Flame Seedless grapes. Abd El-Migeed et al., (2007) on Thompson seedless grapevines, they found that more reduction in nitrate and nitrite content was obtained when bio- fertilizers especially Pseudomonas was added to the combined application of $50 \%$ mineral $\mathrm{N}$ fertilization $+50 \% \mathrm{FYM}$. This positive role of bio-fertilizers in reducing nitrate and nitrite in berries juice revealed the importance of adding bio-fertilizers to vineyards fertilization program.

The use of organic and bio-fertilizers induced a further reduction in $\mathrm{No}_{3}$ $\mathrm{N}$ accumulation in the plant compared with mineral nitrogen. This could be attributed to high available nitrogen release form the chemical fertilizers which increase the rate of nitrogen uptake by plant than its assimilation rate in which increase the rate of nitrogen uptake by plant therefore store as $\mathrm{NO}_{3}-\mathrm{N}$ in plant cells (El-Sisy, 2000) which, the accumulation of nitrate in plant parts is a natural phenomena that occurs when the uptake of $\mathrm{NO}_{3}-\mathrm{N}$ by roots exceeds it reduction and subsequent assimilation within the plant. The amount, source and timing of nitrogen application may be play clear role on $\mathrm{NO}_{3}-\mathrm{N}$ accumulation in the plant (Khalil, Hoda, 2012). However, organic nitrogen in combination with mineral nitrogen fertilizer resulted in less accumulation of $\mathrm{NO}_{3}-\mathrm{N}$ than mineral fertilizer application alone.

Undesirable effects of a high nitrate intake on human health particularly on the health of babies, up to about 4 months of age are reported. Nitrate inside the body is rapidly reduced into nitrite form in the intestinal tract, and absorbed into blood stream. The risk of methaemoglobinaemia in infants and the possibility of an increase in the incidence of cancers in adult. It is currently accepted that intake of nitrate implies a risk of methaemoglobinaemia (blue baby syndrome) for young infants. The hemoglobin molecule in the red blood cells has the important function of transporting oxygen. Methaemoglobinaemia is an oxidized form of hemoglobin that is oxidized, from the $\mathrm{Fe}^{2+}$ to $\mathrm{Fe}^{3+}$ state. If the methaemoglobinaemia level is abnormally high, the condition is known as methaemoglobinaemia (Sulotto et al. 1994).

Possible links were reported between either birth defect or heart diseases and nitrate concentration (Black, 1989). Also, high nitrate intake by the adults is harmful, because nitrite may convert to nitrosamine and causes cancer. 
Table 7. Effect of organic, microelements and bio-fertilizers on nitrate, nitrite of Superior seedless grapevines during 2013 \& 2014 seasons.

\begin{tabular}{|l|c|c|c|c|}
\hline \multirow{2}{*}{ Treatment } & \multicolumn{2}{|c|}{$\begin{array}{c}\mathbf{N O}_{2}-\mathbf{N} \\
\text { (ppm) }\end{array}$} & \multicolumn{2}{c|}{$\begin{array}{c}\mathbf{N O}_{3}-\mathbf{N} \\
\text { (ppm) }\end{array}$} \\
\cline { 2 - 5 } & $\mathbf{2 0 1 3}$ & $\mathbf{2 0 1 4}$ & $\mathbf{2 0 1 3}$ & $\mathbf{2 0 1 4}$ \\
\hline Control & 1.28 & 1.31 & 7.19 & 6.76 \\
\hline Fulvic acid & 1.19 & 1.28 & 7.09 & 6.41 \\
\hline Microelements & 0.97 & 1.20 & 5.66 & 6.24 \\
\hline Bio-fertilizers & 1.01 & 1.16 & 5.89 & 5.86 \\
\hline Fulvic acid + Microelements & 1.06 & 1.00 & 6.20 & 5.13 \\
\hline Fulvic acid + Bio-fertilizers & 1.11 & 1.10 & 6.62 & 5.50 \\
\hline Fulvic acid + Microelements + Bio-fertilizers & 1.16 & 0.92 & 6.86 & 4.70 \\
\hline New LSD at 5\% & 0.04 & 0.04 & 0.08 & 0.07 \\
\hline
\end{tabular}

Bio-fertilizers $=($ Trichoderma viride + Trichoderma harzianum + Serratia sp. + Pseudomonas fluorescens + Bacillus polymyxa) at $7.14 \mathrm{ml} /$ liter /vine.

Micro-elements $=\left(\mathrm{FeSO}_{4} .7 \mathrm{H}_{2} \mathrm{O}\right.$ at $0.36 \mathrm{~g}+\mathrm{ZnSO}_{4} .7 \mathrm{H}_{2} \mathrm{O}$ at $0.18 \mathrm{~g}+\mathrm{MnSO}_{4} \cdot \mathrm{H}_{2} \mathrm{O}$ at $\left.0.18 \mathrm{~g}\right) /$ liter /vine.

Total carbohydrates (\%), Total nitrogen (\%) and $\mathrm{C} / \mathrm{N}$ ratio:

Table 8 clarified that the effect of different treatments on total carbohydrate (\%), total nitrogen (\%) and $\mathrm{C} / \mathrm{N}$ ratio in Superior seedless grapevines canes. As for the percentage of total carbohydrate of the canes, sole and combined application caused a significant increase total carbohydrates in the canes in comparison to control except micro-nutrients treatment, combined application of (Fulvic acid + Bio-fertilizers) achieved the highest significant increase $(28.30 \& 28.60 \%)$ in the two seasons of the study, respectively. This treatment also had significant increase of $\mathrm{C} / \mathrm{N}$ ratio compared with other treatments and the control (61.90 \& $59.90 \%)$ in both seasons, respectively. Whilst, in the second rank was (Fulvic acid + Microelements + Bio-fertilizers) treatment. In case of total nitrogen (\%) obtained data revealed that the highest values were coincided with control treatment, while treatment of fulvic acid + micro-nutrients +biofertilizers gave the lowest values in that respect.

These results are in accordance with those obtained by Mostafa et al., (2008) who found that adding Damietta town refuses (DTR) as organic nitrogen source gave the highest increases in total carbohydrates in the canes as compared with other organic nitrogen sources. Chen et al., (2004) mentioned that humic acids provide sits for microflora to colonize so they stimulate the development of microflora populations being utilized as a substrate (a source of organic carbon) or nutrient source (N, P, trace elements and vitamins).

Foliar fertilizers containing fulvic acids (FAs) in combination with nitrogen, potassium, phosphorus and various trace minerals are rapidly absorbed by the plant leaves. Within 8 hours after applications of humic substances are applied changes in many different metabolic processes are detected. Enhanced carbohydrate accumulation can be detected within 24 to 48 hours after foliar feeding by using of a refractometer. Enhanced carbohydrate production can either result in improved product quality or increased yields (Dixon and Weed, 1989). 
Table 8. Effect of organic, microelements and bio-fertilizers on total carbohydrates (\%), total nitrogen (\%) and $\mathrm{C} / \mathrm{N}$ ratio in canes of Superior seedless grapevines during 2013 \& 2014 seasons.

\begin{tabular}{|l|c|c|c|c|c|c|}
\hline Treatment & \multicolumn{2}{|c|}{$\begin{array}{c}\text { Total } \\
\text { carbohydrates } \\
(\%)\end{array}$} & $\begin{array}{c}\text { Total Nitrogen } \\
(\%)\end{array}$ & \multicolumn{2}{c|}{ C/N ratio } \\
\hline & 2013 & 2014 & 2013 & 2014 & 2013 & 2014 \\
\hline Control & 24.30 & 25.00 & 0.48 & 0.53 & 50.70 & 47.50 \\
\hline Fulvic acid & 25.80 & 27.30 & 0.45 & 0.50 & 56.90 & 54.60 \\
\hline Microelements & 24.80 & 25.50 & 0.47 & 0.49 & 52.00 & 52.30 \\
\hline Bio-fertilizers & 25.30 & 26.60 & 0.46 & 0.50 & 55.50 & 52.90 \\
\hline Fulvic acid + Microelements & 26.40 & 27.60 & 0.45 & 0.48 & 59.10 & 57.10 \\
\hline Fulvic acid + Bio-fertilizers & 28.30 & 28.60 & 0.46 & 0.48 & 61.90 & 59.90 \\
\hline $\begin{array}{l}\text { Fulvic acid + Microelements + } \\
\text { Bio-fertilizers }\end{array}$ & 27.30 & 27.70 & 0.44 & 0.47 & 61.70 & 59.50 \\
\hline New LSD at 5\% & 0.60 & 0.62 & 0.01 & 0.02 & 2.10 & 3.20 \\
\hline
\end{tabular}

Bio-fertilizers = (Trichoderma viride + Trichoderma harzianum + Serratia sp. + Pseudomonas fluorescens + Bacillus polymyxa) at $7.14 \mathrm{ml} / \mathrm{liter} / \mathrm{vine}$.

Micro-elements $=\left(\mathrm{FeSO}_{4} \cdot 7 \mathrm{H}_{2} \mathrm{O}\right.$ at $0.36 \mathrm{~g}+\mathrm{ZnSO}_{4} \cdot 7 \mathrm{H}_{2} \mathrm{O}$ at $0.18 \mathrm{~g}+\mathrm{MnSO}_{4} \cdot \mathrm{H}_{2} \mathrm{O}$ at $\left.0.18 \mathrm{~g}\right) / \mathrm{liter}$ /vine.

The positive effect of bio- organic fertilizers contained micro-organisms in this case may be due to that it produce growth promoting substances such as $I A A, G A$ and cytokinins, which increase the plant growth, this increase in plant growth may be caused as an increase in photosynthetic rate leading to an activation of assimilation rates (Frankenberger and Arshard, 1995). So, it should be recommended the superiority application of (Fulvic acid + Microelements + Biofertilizers) had significant increase of vegetative growth, total chlorophyll content in the leaves, yield, physical and chemical characteristics of clusters and berries, total carbohydrates, total $\mathrm{N}$ and $\mathrm{C} / \mathrm{N}$ ratio in canes of Superior seedless grapevines.

Otherwise, reduces the residuals of nitrate \& nitrite and total acidity in grape berries, so bio-organic fertilizers can reduce the harmful effects of chemical fertilizers on environment and human health alike.

\section{REFERENCES}

Abd El-Hameed M. M. W.; Ali A. G.; Esis A. R. and Ahmed, R. M. (2014). Reducing mineral $\mathrm{N}$ fertilizer partially in Thompson seedless vineyards by using fulvic acid and effective microorganisms. World Rural Obser., 6 (4):36-42.

Abd El- Hamied, Samah Y. (2007). Effect of some natural organic nutrients on Thompson seedless grapevines. Ph. D. Thesis, Fac. Of Agric., Mansoura Univ., Egypt.

Abd El-Migeed, M. M. M.; M. M. S. Saleh and E. A. M. Mostafa (2007). The beneficial effect of minimizing mineral nitrogen fertilization on Washinton navel orange trees by using organic and biofertilizers. World J. Agric. Sci., 3: 80-85.

Abd El- Wahab, M. A. (2011). Reducing the amount of mineral nitrogen fertilizers for Red Globe grapevines by using different sources of organic fertilizers. J. Amer. Sci., 7 (8): 810 - 819. 
Ahmed, A. A. M. A. Megawer; A. E. M. Mansour; N. E. Ashour and R. A. R. Eissa, (2011). Impact of fulvic acid and Spirulina Platensis algae as a bio organic fertilizers for Flame seedless grapevines grown under sandy soil. Res. J. Agric. \& Biol. Sci., 7(2): 287-293.

Aiken, G.R.; D.M. McKnight and P. MacCarthy (1985). Humic substances of soil, sediment and water, New York: Wiley-Interscience.

Akgül A.; S. Kara and H. Çoban (2007). The effects of foliar Zn applications on yield and some quality characters of Sultani Çekirdeksiz (Vitis vinifera L.) C.B.Ü. Appl. Natural Sci. Institute Publ., 3: 183-190. (in Turkish).

Alef, K. (1995). Methods in Applied Soil Microbiology and Biochemistry. 2nd Ed, PP: 360-361. Academic Press Ltd., USA.

Ali, M. A.; R. S. S. El- Gendy and O. A. Ahmed (2013). Minimizing adverse effects of salinity in vineyards. J. Hort. Sci. \& ornament. Plants, 5 (1): 12 $-21$.

AOAC (1984). "Official Methods of Analysis" 13th Ed. Published by the Association of Official Analytical Chemists, Washington DC. USA.

Anonymous, A. M. (1985). International rules for seed testing. Seed Sci Tech., 13: 299-320.

Arnon, D.J. (1949). Copper enzymes in isolated chloroplasts polyphenol oxidase in Beta vulgaris. Plant Physiol., 24: 1-15.

Biocycle (2004). Building a knowledge base for compost tea. J. Composting \& organic Recycling, June, 1-2.

Black, C.A. (1965). Methods of Soil Analsis Chemical and Microbiological Properties (part2). Amer. Soci. Agri. Inc.

Chen, Y. and P. Barak (1982). Iron nutrition of plants in calcareous soils. Adv. Agron., 35: 217- 240.

Chen, P. K. and W. M. Mellenthin (1981). Effect of harvest date on ripening capacity and postharvest lif of Anjou Pears. J. Amer. Soc. Hort. Sci, 106 $: 138$

Chen, Y.; M. De Nobili and T. Avid (2004). Stimulatory effects of humic substances on plant growth. In: F. MAGDOFF; R. R. WEIL (Eds.): Soil Organic Matter in Sustainable Agriculture, 103-129 CRC Press, New York, USA.

Creasy, G. L. and L. L. Creasy (2009). Grapes. CABI Head office Oxford Shire OXIO 8 DE, UK.

Dixon, J. B. and S. B. Weed (1989). Page 95 In "Minerals in Soil Environments".Soi. Sci. Soci. Ameri., Madison, Wisconsin, 1244 pages.

Eissa, E. M. (2003). Effect of some biostimulants on vegetative growth yield and fruit quality of " Kelsey " plum. Egypt J. Appl. Sci., 18(5B): 175- 194.

EL-Gamal, A. M. (1996). Response of photo in the newly reclaimed area to mineral nitrogen levels and nitrogen fixing biofertilizer Halex. Assiut $\mathrm{J}$. Agric. Sci., 27(2): 89-99.

El-Nagar, E. M. (1996). Effect of applying some organic residues to sand calcareous soils on growth and composition of some plants. M. Sc. Thesis, Fac. of Agric., Mansoura Univ. 
El- Sabagh, A. S.; F. M. El-Morsy and A. R. Farag (2011). Effect of bio-fertilizers as a partial substitute for nitrogen on vegetative growth, yield, fruit quality and leaf mineral content of two seedless grape cultivars, J. Hort. Sci. \& Ornamen. Plants, 3(2):166-175.

El-Shenawy, F. E. and T. A. Fayed (2005). Evaluation of the convential to organic and bio-fertilizers on Crimson seedless grapevine in comparison with chemical fertilization. 2-Yield and fruit quality. Egypt. J. Appl. Sci., 20(1): 212-225.

El- Sisy, L. M. H. (2000). Assessing the pollution caused by excessive nitrogen fertilization. J. Agric. Sci. Mansoura Univ., 25(11): 7297 - 7313.

Ezz, T. M. (1999). Response of Thompson seedless grapevines grown in calcareous soil to organic fertilizer "Biotreasure" and cattle manure application. J. Agric. Sci. Mansoura Univ., 24 (4): 1987-1990.

Farag, S.G. (2006). Minimizing mineral fertilizers in grapevine farms. M.Sc. Thesis, Institute of Environmental Studies and Research, Ain Shams Univ., Egypt.

Ferrara, G. and G. Brunetti (2010). Effects of the times of application of a soil humic acid on berry quality of table grape (Vitis vinifera L.) cv Italia. Spanish J. Agric. Res., 8(3), 817-822.

Ferrara G.; A. pacific; P. Simone and E. Ferrara (2007). Preliminary study on the effects of foliar application of humic acids on 'Italia ' table grape. Proc. Of the XXXth World Congress of Vine and Wine.

Frankenberger, W.T. and M. Arshard (1995). Phytohormon in soils, microbial production and function. Marcel Dekker Inc., New York, pp. 305.

Gomez, K. N. and A. A. Gomez (1984). Statistical Procedures for Agricultural Research. John Wiley and Sons, New York, 2nd ed., p. 68.

Grimont, P. A. D. and F. Grimont (1984). Bergey's Manual of Systematic Bacteriology. Williams \& Wilkins, Kneg, N.R. (Eds.), Vol. 1, pp. 477-483, Baltimore, London.

Hedge, I.E. and B.T. Hofreiter (1962). Carbohydrate Chemistry. 7th Ed. Whistler R.L. and Be Miller, J.N. Academic Press, New York.

Jones, I. R.; I. Benton; B. Wolf and H. A. Mills (1991). Plant Analysis. Handbook, Methods of Plant Analysis and Inter-predation. Micro-Macro. Publishing, inc., USA, pp: 30-34.

Kassem, H. A. and H. A. Marzouk (2002). Effect of organic and/or mineral nitrogen fertilization on the nutritional status, yield and fruit quality of Flame seedless grapevines grown in calcareous soils. J. Adv. Res., 7(3): 117-126.

Khalil, Hoda A. (2012). The potential of bio- fertilizers to improve vegetative growth, nutritional status, yield and fruit quality of Flame seedless grapevines. American -Eurasian J. Agric \& Environ. Sci., 12 (9): 1122 1127.

Li, N.; X. Wang and B. L. Lu (1999). Study of the effect of apple liquid fertilizes on the growth and fruit development of starkrimson apple variety. China fruits, 4: 20-21. (C.F. Hort. Abst., 70S: 3628).

Megawer, M. A. (2009). Reducing the amount of inorganic $N$ fertilizers in Superior grape vineyard by using organic and bio- fertilizers and humic acid. Egypt. J. Agric. Res., 87 (1): 317 - 344. 
Mengel, K. and E. A. Kirkby (1987). Principles of Plant Nutrition. 4 th ed., International Potash Institute, Pern, Switzerland, PP : 687.

Montero, F. J.; J. A. De Juan; A. Cuesta and A. Brasa (2000). Non-destructive methods to estimate leaf area in Vitis vinefera L. HortScience, 35: 696698.

Mostafa, M. F., A. Hegazi, M. M. EL-Mogy and B. E. A. Belal (2008). Effect of some organic fertilizers from different sources on yield and quality of Thompson seedless grapevines (Vitis vinifera L.). J. Agric. Sci. Mansoura Univ., 33 (10): 7421-7435.

Nijjar, G.S. (1985). Nutrition of Fruit Trees. Mrs Usha Raj Kumar for Kalyani. Publishers. New Delhi, India, pp: 1-89.

OIV (2006). State of Viticulture World Report. L'Organisation International de la vigne et du vin, Paris, $14 \mathrm{pp}$.

Peterburgski, A. V. (1968). Handbook of Agronomic Chemistry. Kolas publishing House, Moscow, (in Russian), pp: 29-86.

Robinson, J. M. and S. J. Britz (2000). Tolerance of field grown soybean cultivars to elevated ozone level is concurrent with higher leaflet ascorbic acid level, higher ascorbate-dehydroascorbate redox status and long term photosynthetic productivity. Photosynthetic Research, 64: 77-87.

Rizk-Alla, M.S. (2006). Minimizing mineral nitrogen fertilizers in: Flame seedless vineyards through the application of some bio-fertilizers to reduce nitrate and nitrite residues in the berries. Egypt. J. Appl. Sci., 21(2). 90 - 102.

Sanga Khora, U. R. and P. Weerakera (1999). Impact of effective microorganisms on nitrogen utilization efficiency of selected food crops. 6th Inter. Conf. on Kyusei Nature Forming. Conf. Center, Univ. of Pretoria, South Africa.

Shaheen, M. A. G.; Sahar M. Abdel-Wahab; Emad A. Hassan and Adel M. R. A. Abdel Aziz (2012). Effect of some soil conditioners and organic fertilizers on vegetative growth and quality of Crimson seedless grapevines. J. Hort. Sci. \& Ornamen. Plants, 4 (3): 260 -266.

Shamseldin. A. H.; E. Mohamed and S. S. Kabeil (2010). Microbial biofertilization approaches to improve yield and quality of Washington navel orange and reducing the survival of nematode in the soil. J. Amer. Sci., 6(12): 264-272.

Singh, J. P. (1988). A rapid method for determination of nitrate in soil and plant extracts. Plant and Soil, 110: 137-139.

Stino, R. G.; A. T. Mohsen and M. A. Maksoud (2009). Bio-organic fertilization and its impact on apricot young trees in newly reclaimed soil. American - Eurasian J. Agric. and Environ. Sci., 6 (1): 62-69.

Sulotto, F.; C. Romano; A. Insana; M. Carrubba Cacciola and A. Cerutti (1994). Valorinormali di carbossi-emoglobinemia e di metemoglobinemia in un campino de military di leva. La Medicina del lavoro 85: 289-298.

Vallini, G.; A. Pera; G. Sorace; C. Cecchi and P. Manetti (1990). Green composting. Bio Cycle, 31(6): 33-35.

Waller, R. A. and D. B. Duncan (1969). A bays rule for the symmetric multiple comparison problem. J. Amer. Assoc., 64: 1484-1503.

Winkler, A. J.; J. A. Cook; M. M. Kliewar and L. A. Lider (1965). General Viticulture. Univ. Calif. Press, Berkeley and Loss Angeles., London. 
تأثير حـامض الفولفيك مـع بعض العناصر الصغرى والكائنـات الحيـة الدقيقة على

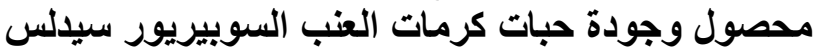

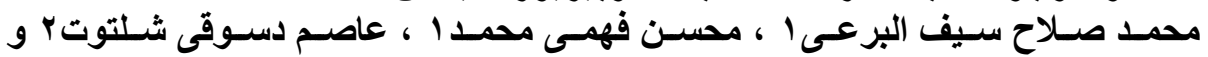

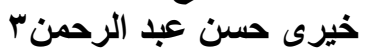

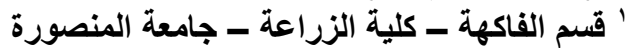

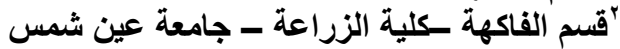

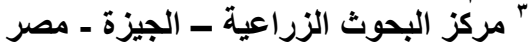

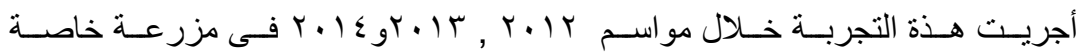

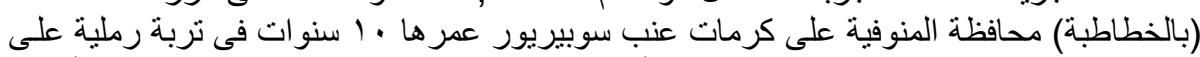

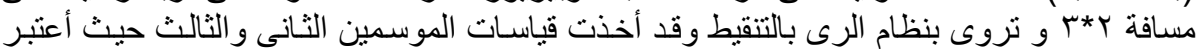

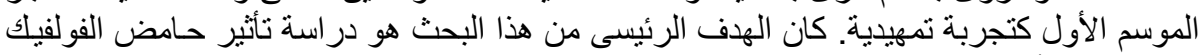

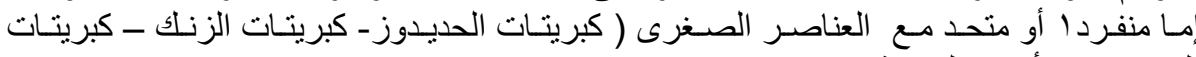
المنجنيز) و الأسمدة الحيوية

(Trichoderma viride + Trichoderma harzianum + Serratia sp. + Pseudomonas fluorescens + Bacillus polymyxa)

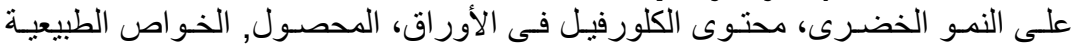

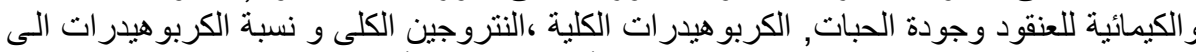

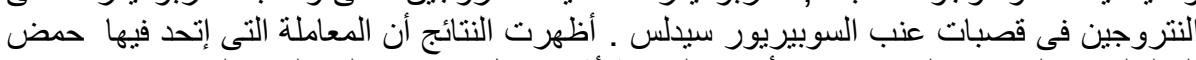

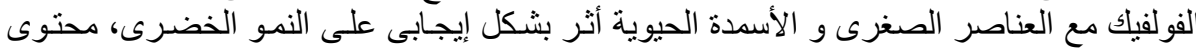

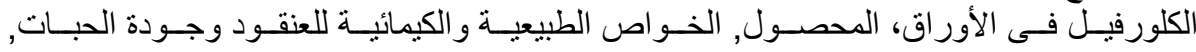

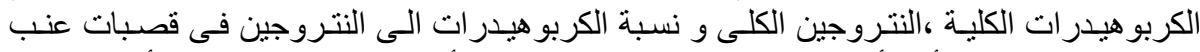

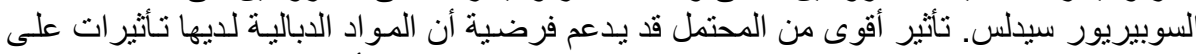

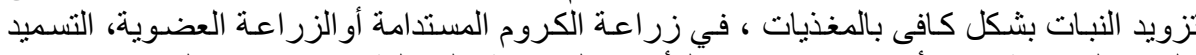

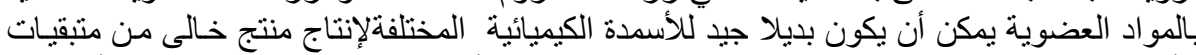

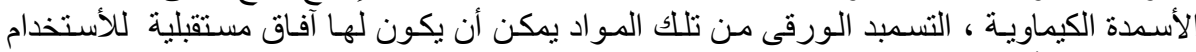

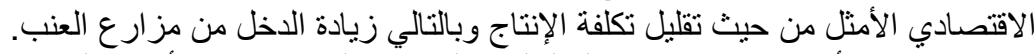

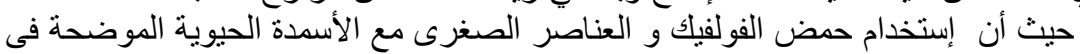

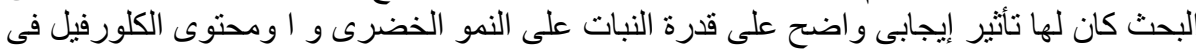

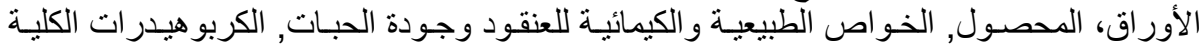

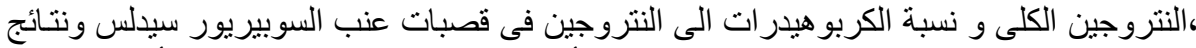

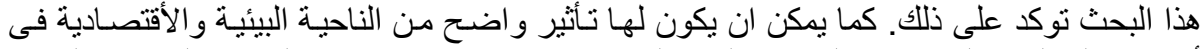

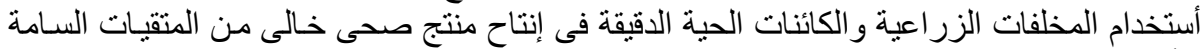

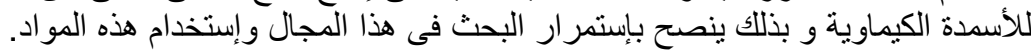

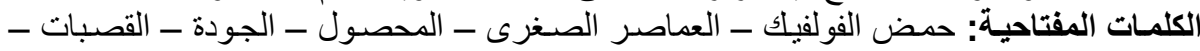

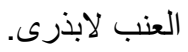

